\title{
Rethinking lonesco's Absurd: The Bald Soprano in the Interlingual Context of Vichy and Postwar France
}

Julia Elsky

Loyola University Chicago, jelsky@luc.edu

Follow this and additional works at: https://ecommons.luc.edu/modernlang_facpubs

Part of the Dramatic Literature, Criticism and Theory Commons, Modern Languages Commons, and the Modern Literature Commons

\section{Recommended Citation}

Elsky, Julia. Rethinking lonesco's Absurd: The Bald Soprano in the Interlingual Context of Vichy and Postwar France. PMLA, 133, 2: 347-363, 2018. Retrieved from Loyola eCommons, Modern Languages and Literatures: Faculty Publications and Other Works, http://dx.doi.org/10.1632/pmla.2018.133.2.347

This Article is brought to you for free and open access by the Faculty Publications and Other Works by Department at Loyola eCommons. It has been accepted for inclusion in Modern Languages and Literatures: Faculty Publications and Other Works by an authorized administrator of Loyola eCommons. For more information, please contactecommons@luc.edu. cc) (i) $\ominus$

This work is licensed under a Creative Commons Attribution-Noncommercial-No Derivative Works 3.0 License. (C) The Author 2018 
$133 \cdot 2]$

\title{
Rethinking lonesco's Absurd: The Bald Soprano in the Interlingual Context of Vichy and Postwar France
}

\author{
JULIA ELSKY
}

JULIA ELSKY is assistant professor of French at Loyola University, Chicago. She is completing a book manuscript entitled "Writing Occupation: Jewish Émigrê Writers and Wartime France." This essay is part of her second book project, on Eugène Ionesco and the origins of the theater of the absurd.

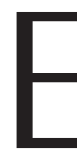

UGÈNE IONESCO'S LA CANTATRICE CHAUVE (THE BALD SOPRANO) IS one of the most performed plays in the world. It debuted in May 1950 at the Parisian Théâtre des Noctambules, and since 16 February 1957, actors at the Théâtre de la Huchette in the Latin Quarter of Paris have been performing it five times a week, following the director Nicolas Bataille's original conception. To date, the Huchette's Le spectacle Ionesco (The Ionesco Show), which includes La cantatrice chauve and La leçon (The Lesson), has been staged over eighteen thousand times and seen by more than two million viewers ("L'histoire"). Throughout most of its performance history, scholars have understood La cantatrice chauve along the lines of an article by Martin Esslin, published in 1960 and later expanded into a book, in which he coined the term "Theatre of the Absurd" to explain the avant-garde theater movement that developed after the Second World War ("Theatre" and Theatre). The movement included figures such as Ionesco, Arthur Adamov, Samuel Beckett, Jean Genet, and Harold Pinter. Esslin focuses on postwar antitheater's representation of passive and empty language, envisioning incoherent language as representing the meaninglessness of language in a conformist postwar bourgeois world. Scholars, even those who react against Esslin's reading, have retained the postwar narrative of the development of the theater of the absurd and thus have not appreciated the extent to which the play is inseparable from its almost unknown dual linguistic political context. It is well-known that in the play Ionesco parodies the Assimil method of the English-language textbook L'anglais sans peine ("English without Pain"), a method that is based on "acquisition automatique" ("automatic acquisition"; Chérel 1) and features a prominent first stage described as "entièrement passif" ("entirely passive"; 2). However, the interlingual implications of the play's origins in

(C) 2018 JULIA ELSKY

PMLA 133.2 (2018), published by the Modern Language Association of America

347 
a language-teaching manual, which by definition crosses language barriers, have yet to be explored. Moreover, little discussion has been devoted to Ionesco's original version of La cantatrice chauve, the Romanian play Englezește fără profesor ("English without a Teacher"), which was written in 1943, during the war, and is in part based on a Romanian-language textbook with a similar name, Engleză fără profesor ("English without a Teacher"). ${ }^{1}$ This version, first published in a Romanian review in 1965 (Ionescu, "Englezește"), takes its inspiration not only from a passive-learning textbook but also from language pedagogies that point to active engagement in language learning. ${ }^{2}$ An interlingual account of La cantatrice chauve and its Romanian origins reveals that in the French version of the play, Ionesco writes about language acquisition as an active political event linked to a specific local context. In the wartime version, language is a tool of political violence; in the postwar version, Ionesco transforms the play to reflect on the possibility of viewing language acquisition as an act of meaning making in the postwar period. By recontextualizing the play, we can reevaluate the long-held view of its place in the theater of the absurd.

If we move beyond the borders of France to explore Ionesco's Romanian background and his work for the Romanian government's delegation to the French collaborationist Vichy government, our view of the play shifts: the play is no longer about meaninglessness. Instead, a multilingual analysis reveals it to be a political play largely about language acquisition. I read La cantatrice chauve in the context of the Romanian version and alongside archival documents dating from Ionesco's career in Vichy France, including La terre roumaine ("The Romanian Land"), his first French play, which was broadcast on Radio Marseille in 1943 and is unknown to critics (Ionesco et al.). In his wartime works, the confrontation between languages in occupied France plays out in the drama of communicating in an ad- opted language. With significant exceptions, recent scholarship avoids discussion of his involvement in Romanian cultural diplomacy under Ion Antonescu's authoritarian military dictatorship while he was in Vichy France composing the original play. ${ }^{3}$ In contrast, I trace Ionesco's double-language experience and its political exploitation. The Romanian play and its context reveal what the translation theorist Lawrence Venuti deems the "ethnocentric violence that is inherent in every translation process" (22). Ionesco was writing during a period of strained and violent relations between those nations whose languages were the topics of the textbooks he used; these were the languages he moved between during the Second World War as a cultural secretary for the Romanian delegation to Vichy France, when English was the language of the enemy. As he was composing Englezește fără profesor, Ionesco was directly involved in wartime propaganda to promote Romanian and Romanian language learning in French universities. The Romanian play depicts language and language acquisition as implements of political violence. In the French version of the play, he almost entirely erases this wartime political dimension. Despite La cantatrice chauve's reputation for indicting language as an empty yet violent gesture, the play is actually an attempt to replace the earlier version's more troubled and more troubling attitude about crossing language barriers with a meditation on how speakers create meaning through language learning. We thus can understand Ionesco in a new way: he was not writing a play revealing the meaninglessness of language in a conformist world; rather, he was envisioning the productive politics of communication across languages.

\section{A Romanian in Vichy France}

Ionesco was not a distant bystander to the linguistic politics of the Second World War. The narrative that casts him as a Romanian 
émigré writer in France who adopted French as his literary language is overly simple. Born in Slatina, Romania, in 1909, raised between France and Romania, he negotiated in his youth a dual-language existence. He wrote of belonging and repeated displacement in terms of language, specifically language acquisition, or, as he put it, "[c]et apprentissage, ce désapprentissage, ce réapprentissage" ("this learning, this unlearning, this relearning"; Entre la vie 23). After finishing his degree in French literature at the University of Bucharest and completing his teaching certification, Ionesco taught high school French in Bucharest in the 1930s. He then began his literary career, publishing literary criticism and joining various circles of Francophile and often Francophone writers. He looked toward France as a cultural center-not only as the capital of the "world republic of letters," to use Pascale Casanova's term, but also as Romania's link to western Europe. After a stay in Paris to start a doctoral thesis, he returned to Bucharest following the French defeat of June $1940 .{ }^{4}$ But almost immediately afterward, Ionesco sought to return to France, especially after Romania joined the Axis powers. He felt that France was his true home and yet later wrote that the only legal way for him to move to France was to take an official post in the Romanian government (Présent passé 183). His bilingual career took an ironic turn when he relocated to France in 1942 as a cultural secretary for the Romanian delegation to Vichy France under Antonescu's military dictatorship. ${ }^{5}$

For the delegation, Ionesco helped organize language learning as a political tool in ways that scholars have previously ignored. He worked on the propaganda team in Vichy France that promoted Romanian and Romanian language learning in France. He was at the heart of Axis propaganda as one of the press secretaries for the Ministry of $\mathrm{Na}$ tional Propaganda (Ministerul Propagandei Naţionale) in 1942 (Mareş 113). Critics usually gloss over this period of his life, when he began to write for the theater; until recently many scholars, with notable exceptions-including Alexandra Laignel-Lavastine, Marta Petreu, Eugen Simion, and Ana-Maria Stanhave ignored it or provided misinformation about it. ${ }^{6}$ The scholars who do discuss this period disagree about how much Ionesco identified with the delegation's politics as well as the exact nature of his activities in France. My focus here is on how his work on Romanian propaganda and his cultural diplomacy in Vichy France influenced his wartime writings' treatment of linguistic exchange-that is, how people communicate across languages and how languages come into contact with each other.

Ionesco arrived in France as a member of the Romanian propaganda team on 30 June 1942, during the period when Antonescu intensified his lobbying of France to support Romanian control of territories that Romania had lost in 1940 to Hungary, one of France's main prewar allies ("Demande" [1957]; Notes 3). ${ }^{7}$ In April 1943, Ionesco became one of the principal cultural secretaries of the delegation and was put in charge of Nice, Toulouse, Montpellier, and Marseille (Dragu, Report 1158, 10; Mareş 113). Rather than government-to-government work, Ionesco's cultural diplomacy targeted the French literary and academic public to gain support for Romania. ${ }^{8}$ His diplomatic and political initiatives included networking, publishing translations of Romanian literature into French, encouraging Romanian language learning, finding positions for Romanianlanguage teachers at the university level, and keeping up with publications in occupied France. A few days before Ionesco arrived in France, his superior, Ion Dragu, wrote a report that summarizes the department's goals in the southern zone. Using military language to emphasize culture's role in the war effort, Dragu explains that propaganda in France is "arma psihologică" ("the psychological weapon"; Report 559, 1) that he 
and his staff members use in an organized, methodical, and scientific manner. He recommends launching a propaganda campaign that speaks to the French through the press and on the radio: "trebuie să îmbrace haina şi să ia toiagul pelegrinului spre a cutreera toate drumurile Franței" ("it must don the coat and take the pilgrim's staff to travel all the roads of France from one end to the other"; 2). The pilgrim metaphor suggests that Dragu wants his staff members to permeate France not as foreigners but as those who belong in France by virtue of the sanctity of their mission. Taking the pilgrim's staff meant understanding, absorbing, and reporting on the political, economic, and cultural atmosphere of France. Romanian officials thus saw language and culture as explicitly political activities. Ionesco now took on the same dual FrancoRomanian linguistic identity of the prewar years but from a strange new position: the war made this disaffiliated Romanian speaker, who identified as a French speaker, into a Romanian official making a pilgrimage to France. At the same time, this constant navigation between French and Romanian took place as martial propaganda combated a third hostile language: Hungarian. The propaganda was part of a strategy designed to contest Hungary's claims to northern Transylvania, which had been part of Romania from 1918 until 1940, when Germany and Italy gave it to Hungary in the Second Vienna Award.

Nevertheless, Ionesco's national and ethnic position in the delegation had gray areas. While at the heart of authoritarian propaganda of one of the most important countries involved in Axis propaganda, Ionesco maintained ties with Jewish intellectual friends. He located and cultivated networks that were collaborationist or critical of Vichy France: on the one hand, the right-wing, anti-Semitic French writer Paul Morand (his counterpart working for France in Romania); on the other, Jean Ballard, at the Cahiers du Sud, who helped many Jewish intellectual refugees. Io- nesco even hired the Romanian Jewish émigré poet Ilarie Voronca, who was living in hiding in Rodez, France, to write official translations from Romanian into French under a pseudonym. ${ }^{9}$ Ionesco's actions leave his position ambiguous at best. Clearly, however, his view of the politics of language learning and his belief in theater's capacity to express them were shaped by his career in Vichy France.

Ionesco's ambivalent position in Vichy France as a promoter of Romanian language and culture is crucial to understanding his composition of Englezește fără profesor, in which Ionesco engages with language pedagogies and manuals. He began the work around 1943, while he was negotiating his role in wartime France as a Romanian diplomat promoting the study of Romanian to the French. Englezește fără profesor is shorter than $\mathrm{La}$ cantatrice chauve, since it does not include the French version's fireman scenes (from the middle of scene 7 through scene 10), and features a radically different ending. ${ }^{10}$ Whereas many of the dialogues are almost identical in the two versions, and whereas, like La cantatrice chauve, the Romanian version draws on the Assimil English manual with its grammar-translation method, Englezește fără profesor also draws on other Romanian textbooks with significantly different pedagogies. It opens with the Smiths' discussion of their acquaintances and favorite foods: "D-na Smith: E ora nouă. Am mîncat supă, pește, carne cu cartofi, salată și am băut bere. Copiii au băut apă. Am mîncat bine, astăseară" ("Mrs. Smith: It is nine o'clock. I ate soup, fish, meat with potatoes, salad and I drank beer. The children drank water. I ate well, this evening"; Ionescu, "Englezește” 58). Ionesco follows the type of exercises commonly found in language manuals, which typically ask students to discuss where they live, their family situations, and other details of daily routines. Mr. and Mrs. Martin stop by for dinner. The characters utter commonplaces in Romanian and in English, like "Casa unui englez 
este adevăratul său castel” (“An Englishman's house is his true castle"; 63) and "Charity begins at home" (64). ${ }^{11}$ Rhyme is featured in seemingly nonsensical lines that resemble false adages, for example: "Mai bine o leasă într-o casă, decît o plasă într-o rasă" ("Better a thread in a shed than a lace in a race"; 63). ${ }^{12}$ But a deeper study of the wartime context of the Romanian play, as well as its basis in Romanian textbooks and in Assimil, challenges our understanding of the text as an absurdist play filled with meaningless language.

Ionesco wrote this play with his knowledge of language pedagogy that, unlike Assimil, implicitly acknowledges and attempts to overcome the difficulty of language exchange through active learning. He would have learned this pedagogy at the University of Bucharest in preparation for his teaching certification before he moved to France. Englezește fără profesor draws on language manuals other than Assimil, manuals that involve far more active participation by the language learner. Although a 1930s version of Engleză fără profesor is nowhere to be found, the Central University Library of Bucharest holds numerous language manuals from the period, potentially the very books Ionesco might have consulted: I am learning English: Curs practic de limba engleză ("I Am Learning English: Practical English Language Course"), by Ion-Aurel Candrea (1938); English book for the first year: Metoda Maud Griffiths-Belbin ("English Book for the First Year: The Maud Griffiths-Belbin Method"), by Sanda I. Mateiu (1937), which follows the method of the tutor to the children of Marie, queen of Romania; and Curs de corespondență comercială engleză ("Commercial English Correspondence Course”), by Zoe Ghetu (1935). ${ }^{13}$ Unlike Assimil, the approach of these textbooks is heavily grammatical, with many grammar charts and rules, requiring active participation by the student at all stages. Instead of being divided into active and passive stages, these textbooks contain sections as well as dialogues linked to active engagement with phonetics, lexical principles, spelling, and advanced grammar. Later sections revolve around readings with exercises.

Ionesco incorporates into the Romanian version of the play elements of these kinds of language manuals, in addition to those of Assimil, not to argue that language is meaningless but rather to demonstrate the strange and often chaotic process through which language learners create meaning. As the Martins wait for the meal to be served, the situation devolves into chaos. Ionesco features the repetition of sounds and letter pronunciations along with lines of nonsensical alliterations and conventional sayings. Four lines of dialogue are not just individual letters but also phonemes-“A, e, i o, u, a, e, i . . bî̀, cî, dî, fî, gî ... oaie, aie, uie, oa, ea, ua, ou, ou, ou"and six sections of sound repetition (Ionescu, "Englezește" 65). The repetitions feature the words "castraveții" ("cucumbers"; 64), "întîi cucoanele" ("ladies first"; 64), followed by "întîi cuptoarele" ("ovens first"; 64), the nonsensical "oubou" (65), and the scatological rhyme "casă căcasă" (a play on "house" and "excrement"; 64), as well as the name Andrei Marin (65). This combination of random words, which perhaps include a reference to Alfred Jarry's Ubu roi, resembles the kind of knowledge gained in the first sessions of a language class. The name Andrei Marin is not a random choice, as has long been thought; it was the name of Ionesco's high school teacher of ancient Greek, who was principal when Ionesco taught at the same high school from 1940 to 1942 (Register). The sounds at the end of Ionesco's Romanian play are not meaningless repetitions, a parody of a language manual. They are the kinds of sounds students repeat to practice pronunciation when they learn a new language. They are not nonsensical; they construct the foundation of meaningful expression in another language. Their seeming impenetrability registers the difficulty of moving from one language to 
another. They correspond to phonetics exercises, which are done with vowel charts or lists of consonants and useful words to practice those sounds. For example, Mateiu's textbook asks students to practice front vowels through reading a chart that lists the words bead, bid, bayed, bed, bared, and bad; then the students must read back vowels in a chart, using the words cooed, could, code, cud, card, cord, and cod (16). ${ }^{14}$ In the light of the language manuals, the Romanian play appears as a text that stages not the meaninglessness of language but rather its building blocks. It highlights pedagogy and thus dramatizes how language learners confront a new language and struggle to communicate through new sounds. The Romanian, French, and English languages that come together show the particular struggle to create meaning in speech in a polylingual setting. The play, and the pedagogy on which it is built, constitute a meditation on the ramifications of multilingualism and language acquisition. The play does not adopt a language manual to highlight the absurdity of language. The characters' shouting and fighting at the end of the dinner party do not prove the emptiness of their words; instead, they fight precisely to communicate through language acquisition.

Ionesco's work for the delegation during the period when he wrote Englezește fără profesor renders the elements of linguistic practice borrowed from textbooks distinctly political. The shouts at the dinner party in the play reveal a struggle for meaning making in language learning but in a particular wartime context. More specifically, Ionesco's reports on his translation propaganda projects, in which the playwright spells out the linguistic policy of the Romanian delegation, suggest that language in the play is far from meaningless-quite the contrary. Ionesco was acutely aware of the meaning and utility of language acquisition for authoritarian politics. Language is not to be derided; its multilayered history is to be exploited as a "psychological weapon" for political purposes. This exploitation is the basis of violence in the play.

A project Ionesco worked on the year before writing Englezește fără profesor provides some insight into his thoughts on the politics of language exchange during the war. By September 1942, Ionesco was in contact with Ballard about creating a special issue of Cahiers $d u$ Sud that would include French translations of Romanian poetry (Ionescu, Report 576). Ionesco had also considered the journal Pyrénées for similar purposes. He was working to publish Romanian literature in noncollaborationist journals as a form of propaganda. First, publishing in a French literary journal, rather than in a propaganda organ, would give the delegation direct access to larger French audiences. Second, Cahiers du Sud (like Pyrénées) represented French Mediterranean culture; the journal's inclusion of Romanian texts in translation would underscore Romanian's status as a Romance language linked to the Mediterranean world (Ionescu, Report 783). These translations would thus connect Romania to France and provide a linguistic kinship that secured their wartime ties (Ionescu, Report 576, 2). Ionesco used Romanian poetry to elevate Romanian to the status of "occidental," in his terms, and to exclude its Eastern or, as he puts it, Balkan associations. In his diary from the 1940s he writes, "Une 'culture' balkanique originale et authentique ne peut être vraiment européenne. L'âme balkanique n'est ni européenne ni asiatique. Cela n'a rien à voir avec l'humanisme occidental" ("An original and authentic Balkan 'culture' cannot really be European. The Balkan soul is neither European nor Asian. It's nothing like occidental humanism"; Présent passé 181). ${ }^{15}$ The higher registers of Romanian literature, he continues, are only imported through French and German literature. Here, Ionesco expresses more than Francophilia; he deems the eastern facets of Romanian literature and culture to be inferior. For Romanian intellectuals, the Balkans signified a Romanian Ori- 
ent and served as markers for antimodernism (Spiridon 381). ${ }^{16}$ The use of language-informed by the delegation's psychological weapons-for wartime alliances was driven by cross-linguistic exchange through selective translation and assertions about language affinity. Englezește fără profesor's closing scenes of fighting take on these invented hierarchies of national languages.

One year later Ionesco was involved in another project that explains even further the violence of language exchange in Vichy France: the hitherto unknown radio play $L a$ terre roumaine, which openly exposes the violence between national languages. Ionesco collaborated on the play, broadcast by Radio Marseille on 29 September 1943, as part of his work for the Romanian delegation (Ionescu, "Asupra"). The radio transcript of the play indicates that he translated the Romanian poems into French and transformed them into dialogues, but-most important-in his reports to the Ministry of National Propaganda, Ionesco noted that he controlled the entire project (Ionesco et al.). La terre roumaine is about the richness of Romanian culture and language. "Voix" ("Voices"), rather than characters, speak in French of Romania's beauty and recite traditional folktales and modern poetry. The play, which includes translations of Tudor Arghezi's poetry, as well as texts by Morand, reveals the linguistic policy of the Romanian delegation to Vichy France at a time when different languages were sites of contestation. In a twist on his dual linguistic experience, Ionesco now uses French to extol the Romanian language in this Frenchlanguage radio broadcast. He depicts the Romanian language as a Latin-derived language, a major element in delineating the link to the "Occidental" (Présent passé 181), echoing the alliance with Vichy France and distancing Romania from an orientalized Balkans (Ionescu, Report 939, 3). Ionesco's other contributions to radio programming include the show Harmonies européennes ("European
Harmonies"), which was broadcast on Radio Paris in October 1943 and again in January 1944 (Radio announcement [13 Oct. 1943] and Radio announcement [25 Jan. 1944]). The profile of the radio stations on which Ionesco's work was aired is conspicuously indicated by a different show that he did not write but that immediately followed Harmonies européennes: Les Juifs contre la France ("The Jews against France"; Radio announcement [25 Jan. 1944]). The juxtaposition of these broadcasts illustrates how he was implicated in the alliance between occupied France and Romania under Antonescu.

In his praise of linguistic diversity in Romanian, Ionesco acknowledges the violence underlying language. Romanian is made up of the languages of invading forces: Latin and Greek first, then Slavic languages and Turkish. The first scene of La terre roumaine, in which the voices talk about the richness of Romanian, suggests that the source of this linguistic wealth is war and invasion (Ionesco et al.):

1E vorx: Craiova, Cetatea, Alba, Cernautsi ... 2E voIX: Constantza, Braila, Bucuresti ...

3E VoIx: Iasi, Ploesti, Bagargig ...

4E voIX: Villes roumaines.

1E volx: Noms aux consonances variées venues des différents idiomes de ceux qui tour à tour les ont faites, les ont détruites, ou ont contribué à les reconstruire, comme ils ont contribué à faire leur langue.

2E voIx: Noms latins!

3E voIx: Noms grecs!

4E voIX: Noms slaves!

1E voIX: Noms turcs!

2E voIx: Noms fondus et harmonisés dans le nom qui les englobe tous! Tara Romaneasca, La terre roumaine.

(2; ellipses in the original)

voice 1: Craiova, Cetatea, Alba, Cernăuți ...

voICE 2: Constanța, Brăila, București ...

volCE 3: Iași, Ploești, Bagargig ...

VOICE 4: Romanian cities.

VOICE 1: Varied-sounding names that come from the different idioms of those who in their turns made them [the cities], destroyed them, 
or contributed to reconstructing them, as they contributed to making their language.

VOICE 2: Latin names!

VOICE 3: Greek names!

VOICE 4: Slavic names!

VOICE 1: Turkish names!

VOICE 2: Names merged and harmonized into the name that embraces them all: Țara Românească, the Romanian land. ${ }^{17}$

Even while celebrating language, Ionesco couches words in terms of war and invading populations. He accepts violence as the basis of language exchange, glorifying Romanian not as a pure national language but rather as an amalgam of languages achieved through the violent interaction of nations. One linguistic source that is conspicuously absent from the dialogue in the play is Hungarian: Ionesco likely omitted it because of the long battles between Hungary and Romania to control Transylvania. Their hostile rapport can be seen in the many reports on Hungarian propaganda in the Romanian Ministry of National Propaganda files.

The political ending of Englezește fără profesor, which represents the most striking difference from the later French version, and its comment on the role of nationalism in the theater, clearly link it to La terre roumaine and to Ionesco's propaganda activities. Englezește fără profesor's ending stages the inherent violence in language controlled by the state. The concluding scene, the dinner at the Smiths', is revealed to be a play within a play. The Smiths and the Martins, we learn, have been performing scenes watched by a fictional audience, one that is provoked by the play's final lines. The Smiths announce that the dinner of "piftie de escremente de pasăre" ("jellied bird excrement," a play on head cheese [piftie de porc]) and "pipi de iapă" ("mare pee") is served. Mr. Martin exclaims while "rîzînd de plăcere" ("laughing with pleasure”): “O, domnule, vreți să glumiți!” ("Oh, sir, you must be kidding!"), as the orchestra plays, but mutely, "O Tannenbaum" (Ionescu, "Englezește" 65). The orchestra stops;
Mr. Martin leaves the stage. The play within the play ends, and the fictional audience grows angry that the entire play is a prank; a longawaited dinner turns out to be bodily waste on a plate. Twenty fictional audience members storm the empty stage, yelling and wielding clubs. Then comes the sound of machine guns, and the audience members fall dead. The authorities arbitrarily defend the author and their authority over language. The commissioner of police and "jandarmi în uniformă" ("gendarmes in uniform") barge onto the stage along with the fictional author and theater director. The director congratulates the commissioner, and the author thanks the director for defending him against "măgarii ăștia" ("these asses"), pointing to the fictional audience. The director insults the remaining "îngroziți" ("terrified"; 65) fictional audience members, calling them dogs, and uses questionable logic to exclaim that they have no place in the theater. The director calls on one audience member and asks his profession; he answers that he is a cobbler. $\mathrm{He}$ is told cobblers belong at the shoe repair shop. The director repeats the process with a doctor and a washerwoman. The author intervenes in the conversation:

AUTORUL: De ce veniți aici și ne-ncurcați? Eu mă duc să fac ghete în locul cismarului, să spăl rufe în locul spălătoresei, să-ncurc pe doctor la spital? $\mathrm{Nu}$. Eu aici sînt doctor și-mi văd de treaba mea. Cismarii la cismărie, actorii la teatru, fiecare să-și vadă de treaba lui și lumea o să meargă mai bine. UN ALT SPECTATOR (DIN FUNDUL SĂLII, SE RIDICă): Dar spectatorii, la spectacol.

COMISARUL (ROȘU DE FURIE): Cum îndrăznești să vorbești, cînd eu tac, obraznicule? (Către toată sala): Derbedeilor, să vă astîmpărați, să vă băgați mințile în cap, să vă fie învățătură de minte! (Arată cadavrele pe de scenă): Cum au pățit ăștia, așa puteți să pățiți și voi. (Către sală): Voi ști să apăr cea mai nobilă instituție de cultură națională, teatrul, acest templu de actrițe. Dreepți! Ieșiți afară! Să nu vă mai prind aici! (65-66)

THE AUTHOR: Why do you come here and get in our way? Do I go and make boots instead of the 
cobbler, wash clothes instead of the washerwoman, get in the doctor's way at the hospital? No. Here I am the doctor, and I mind my own business. Cobblers in the shoe repair store, actors in the theater; people should attend to their own business and the world will run more smoothly.

ANOTHER AUDIENCE MEMBER (FROM THE BACK OF THE ROOM, STANDS UP): But spectators at the spectacle.

THE COMMISSIONER (RED WITH ANGER): How dare you speak, when I'm quiet, cheeky fellow? (To the entire room): Rascals, quiet yourselves down, knock some sense into your heads, let this be a lesson to you! (He indicates the corpses on stage): As it happened to them, so it can happen to you. (To the room): I will know how to protect the noblest institution of national culture, the theater, this temple of actresses. Attention! Get out! I had better not catch you here again!

The author-as-character turns out to be on the side of the authorities who hold that the theater represents national culture. Ionesco invites the spectator to see that languagehere, dramatic language inspired by language manuals-is subject to political situations and that the authorities deem theatrical language a tool for upholding national identity. Ionesco, however, questions the control of national language; when Mr. Martin asks if the talk of excrement for dinner is a joke, he also seems to be asking if the entire play, the entire linguistic approach, is a prank. When the audience members protest, as if to question the language on stage, they are met with machine guns. The play contains a strange mix of terror and laughter. The authors of La terre roumaine, like the fictional author of Englezește fără profesor, did glorify national language on behalf of the authorities. The interlingual dialogues-interlingual because they are based on manuals to learn a second language-are controlled by a nationalist program that declares the dominance of Romanian. Through his work in the Romanian delegation, Ionesco involved himself in the same drama of political control over language, a drama he put on stage in Englezește fără profesor. In the play, he seems to be admitting-and expressing discomfort with-his role in the Romanian authorities' propaganda, as well as portraying ambivalently how language acquisition becomes an instrument of the state-something he could do only in a play that was never produced and that was possibly never intended to be produced.

\section{La cantatrice chauve in Postwar France}

Although a hallmark of postwar theater, $L a$ cantatrice chauve has roots in its wartime history. The context of the 1943, Romanian version, and Ionesco's particular wartime view on the status of linguistic contact, enable a new reading of the play. Ionesco began to write the French version that scholars and students know today around 1948 in his adopted home of Paris. He attempted to focus, not on the context of wartime political violence, but on the struggle to create meaning in an adopted language. The play should be seen in the light of his engagement in language acquisition and not understood as a commentary on the meaninglessness of language in a conformist world.

Ionesco's use of the Romanian language manuals challenges the common assumption that La cantatrice chauve is based on the mostly passive-learning method and repetitive quality of the Assimil textbook and is thus a commentary on the emptiness of language. In 1929 Alphonse Chérel created the Assimil method, which focuses heavily on listening and repeating dialogues. It is divided into two phases. The first is passive: learners simply repeat the lines they hear on the recordings that come with the textbook. Assimil is short for assimilation, and learners are meant to assimilate language knowledge. Only after the fiftieth lesson does the active stage begin. In this stage, learners are expected to compare French and English versions of the dialogues. Esslin (Theatre 137), Emmanuel Jacquart ("Notice" 1462), and others have taken the passive 
method of the Assimil textbook as proof that the play is about the passivity and ineffectiveness of language and thus a source for the absurd, or derision of the human condition. As he does in Englezește fără profesor, Ionesco condenses dialogues from Assimil and includes clichés like "Charity begins at home" (La cantatrice chauve 40), as well as seemingly meaningless rhymes and sounds. Scholars have connected the repetition reminiscent of the Assimil method to the emptiness of language and the absurdity of bourgeois life, through clichés and empty speech that disintegrate into sounds. However, Ionesco's previous work on language in the ministry and as a teacher, and his use of the Romanian manuals in the precursor of La cantatrice chauve, indicate that Ionesco was an active professional in language education and a member of the political establishment that put in place each building block of language.

The play has typically been read only in terms of meaningless clichés in the postwar context. According to Esslin's foundational reading, the displacements and alienation of the war years, forced or voluntary, caused an upheaval that changed absurdist playwrights' view of the world after the war. Esslin notes especially that the major figures of the absurd were exiles:

[T] he exile, from his country or from society, moves in a world drained of meaning, sees people in pursuit of objectives he cannot comprehend, hears them speak a language that he cannot follow. The exile's basic experience is the archetype and the anticipation of twentieth-century man's shock at his realization that the world is ceasing to make sense.

(Introduction 18)

In Esslin's reading, the writer who is displaced by the horrors of war and as a result adopts a strange language is in the ideal position to see that the world no longer makes sense. It is a world in which language ceases to function. Esslin's theater of the absurd fea- tures "a radical devaluation of language" that reflects the meaninglessness that writers saw in the ravages of postwar Europe (Theatre 26). His belief that the play parodies a language textbook only seems to demonstrate further that for Ionesco, writing after the war and in reaction to its horrors, language did not function or contain meaning. Esslin confirms this view of the playwright by citing an essay that Ionesco wrote in 1958, entitled "La tragédie du langage" (“The Tragedy of Language"). In it, Ionesco explains that La cantatrice chauve is about the vacuity of language (any language) in the petit bourgeois conformist world that followed the war:

Il s'agit, surtout, d'une sorte de petite bourgeoisie universelle, le petit-bourgeois étant l'homme des idées reçues, des slogans, le conformisme de partout: ce conformisme, bien sûr, c'est son langage automatique qui le révèle. Le texte de La Cantatrice chauve ou du manuel pour apprendre l'anglais (ou le russe, ou le portugais), composé d'expressions toutes faites, des clichés les plus éculés, me révélait, par cela même, les automatismes du langage, du comportement des gens, le "parler pour ne rien dire."...

It is above all a matter of a kind of universal petite bourgeoisie, the petit bourgeois being the man of preconceived notions, of slogans, the conformism that is everywhere: this conformism, of course, is revealed by its automatic language. The text of The Bald Soprano or the manual for learning English (or Russian or Portuguese), composed of ready-made expressions, of the most hackneyed clichés, revealed to me, in this very way, the automatisms of language, of people's behavior, the "speaking to say nothing." ...

According to Ionesco, clichés and seemingly meaningless lines of dialogue express conformists' inability to think and speak for themselves. Despite the languages Ionesco lists, Esslin assumes that the playwright is criticizing the Communist bloc in the post- 
war period. For all his cultural acumen, Esslin understood Ionesco's absurd theater as a strictly postwar phenomenon, but Esslin's argument and periodization need to be rethought. Ionesco associates the play with the victors of the war (England, the United States, Russia) and with a neutral country, albeit one with a fascist ruler (Portugal). Ionesco, in Esslin's view, thus avoids the politics of language acquisition on which he centered the play written in Romanian during the war.

Other scholars, such as Jacquart (Théâtre 33) and Michael Y. Bennett (10), have taken Esslin's reading to task and shown that Ionesco is instead exploring how to find meaning in the absurd universal human condition. They disagree with Esslin's assumption that the playwrights of the absurd accept that life is futile. Yet despite their contributions, they write within the framework of Esslin's postwar view of Ionesco's postwar pronouncements about postwar language. Similarly, scholarship on Ionesco's experience of immigration addresses the bilingual quality of the play but still links it to the alienation of exile, the breakdown of language, and the absurdity of language (Chafee 180; Hubert 62-64). In one of the few texts that analyze the original, Romanian play, Alexandra Hamdan, who dates Englezește fără profesor to 1948 rather than to 1943, argues that the French play is a purposely "'bad' translation" ("une 'mauvaise' traduction") of the Romanian version, and a "parody of translation" ("une parodie de la traduction"; 163). Ionesco's literal translations from the Romanian into the French create a hybrid and seemingly nonsensical language. They also take "la désarticulation du langage à son paroxysme" ("the disarticulation of language to its limit"; 21).

Ionesco deliberately removed the theme of language violence in the postwar publication but not the fact that language contains meaning. By separating the play from its original political context, he shifted the focus away from language exchange as a political tool of violence, instead expressing how learning a new language conveys meaning (and not only political messages). La cantatice chauve should be read as a play about exchange across languages. In addition, we might reexamine Ionesco's "La tragédie du langage," the essay that Esslin uses to define the theater of the absurd, to revisit the question of language. Ionesco devotes only a small portion at the end of this essay to the emptiness of language, "parler pour ne rien dire" ("speaking to say nothing"; 159); in fact, most of the essay is about learning a new language. His interest in interlingual exchange is one expression of his concern with the process of language learning that recurred throughout his long literary career. His interest in exile and alienation is another, but perhaps not the central one, as has been argued. Furthermore, the essay is the text of a talk Ionesco gave at the Institut Français in Italy, which organized courses in French for Italian speakers. In his speech, he related that he first thought he had failed to learn English, despite his use of the Assimil method. But then he had a realization: "Il ne s'agissait plus pour moi de parfaire ma connaissance de la langue anglaise" ("For me, it was no longer a matter of perfecting my knowledge of the English language"). His goal was no longer "enrichir mon vocabulaire anglais, apprendre des mots, pour traduire en une autre langue ce que je pouvais aussi bien dire en français, sans tenir compte du 'contenu' de ces mot, de ce qu'ils révélaient” (“to enrich my English vocabulary, to learn words, in order to translate into another language that which I could just as easily say in French, without taking into account the 'content' of these words, of what they revealed"). He realized he had succeeded in an unanticipated way when he reread his notes and copies of lines of dialogue from the textbook: "Mon ambition était devenue plus grande: communiquer à mes contemporains les vérités essentielles dont m'avait fait prendre conscience le manuel de conversation francoanglaise" ("My ambition had become greater: 
to communicate to my contemporaries the fundamental truths that I was made to learn by my Franco-English conversation manual"; 157). Studying a second language revealed "fundamental truths," truths he knew but had never really thought about. Learning a new language also awakened a need to "communicate" them.

Banal statements are fundamental truths, arrived at through another language. The themes of time, travel, and family, taken from language manuals, reveal how people experience temporal and familial structures in their daily lives. For example, in La cantatrice chauve, Mr. Smith tells Mrs. Smith on which days of the week the Bobby Watsons (all traveling salespeople) have the least competition: "Le mardi, le jeudi et le mardi" ("Tuesdays, Thursdays, and Tuesdays"; 14). Instead of reading this as nonsense, we should see it as a reflection on the human experience of the week-namely, some days seeming like repetitions of the previous day. Throughout the play, the clock strikes numbers that are different from the actual time or strikes numbers out of sequence: first, seven o'clock, thenmoments later-five o'clock. A language learner almost always encounters this notion of nonlinear time in a typical textbook reproduction of different images of clocks that students are meant to read aloud (Candrea 101-02). Again, nonlinear time is not absurd but rather a representation of how time does not seem to move regularly, especially during a boring conversation or at an uncomfortable dinner party. Another common textbook theme, travel by train (220-24), becomes a reflection on marriage. In La cantatrice chauve, Mr. and Mrs. Martin reason backward that they do in fact know each other from the train but also from their marriage and bedroom (scene 4). Instead of highlighting the absurd here, Ionesco shows how a married couple can no longer recognize each other, or how a couple can live together for years and not truly know each other. The banality of these truths, or the truth of these banalities, makes their communication even more poignant. Ionesco experienced the enormity of these truths and banalities only by encountering them in his nonnative tongue. He based his play on language manuals and included what could appear to be meaningless clichés, not to show that language fails to convey meaning, but to explore how interlinguistic exchange leads to discovery.

In "La tragédie du langage," Ionesco describes this kind of writing as "théâtre didactique" ("didactic theater"; 157). According to him, didactic theater should not be original but transmit received knowledge. He is drawing on a practice of language teaching that goes back as far as the Renaissance. As Mary Thomas Crane and Susan Miller have shown, adages and citations drawn from commonplace books have long been used to teach languages. ${ }^{18}$ The sayings in La cantatrice chauve are not clichés; they are loci communes, or commonplaces, in the tradition of received wisdom transmitted from one language to another. Only at the end of "La tragédie du langage" does Ionesco discuss what critics commonly focus on: that while he wrote it, the play was turned upside down, and his intelligent characters began to speak incoherently, as fighting broke out among them. $\mathrm{He}$ realized he was not writing didactic theater but something else, "la tragédie du langage." It is only at this point, at the end of the essay, that he realizes that the breakdown of "didactic theater" - a result of conformism, or loss of individuality and interior life-leads to empty language. Words and speech attain meaning as they move from one language to another. So too in the play, meanings found in translated adages of discovery-not clichés-break down only after cross-linguistic truths collapse.

Yet traces of the violence of multilingualism from the war years remain in La cantatrice chauve. Reading the Romanian version draws out the incipient violence of the French 
version, in which the meal never arrives and in which a fireman comes in hope of finding a fire, since business has been slow. The play loops back to the beginning and starts again in an endless cycle, this time with the Martins in place of the Smiths in the opening scene. The ending is often directed as escalating into shouts and anger (La cantatrice chauve [Bataille]; La cantatrice chauve [Lagarce]). But the violence on display is not about the ferocity of conformity; rather, it is a trace of the linguistic politics of the Second World War. In the Romanian version, the political ending that links the theater to national values clarifies the surprising moment in the French version when the firefighter explains that only some people in England have the right to have their fires put out: the neighbor Durand "n'est pas Anglais. Il est naturalisé seulement. Les naturalisés ont le droit d'avoir des maisons mais pas celui de les faire éteindre si elles brûlent" ("is not English. He's only naturalized. Naturalized people have the right to own houses but not to have them extinguished if they are burning"; Ionesco, La cantatrice chauve 30). This seemingly out-of-place mention of citizenship may refer back to the origins of the play and Vichy France, where a lower level of rights and, eventually, the dissolution of even those rights for the recently naturalized were major topics. In the French play, the French character, Durand, who has a common French name, is the foreigner. Ionesco reminds us we have been in a double-language situation; we have been hearing English spoken in French. Even someone who seems as though he should belong, a Frenchman in a play mostly in French, is linguistically displaced as the characters ventriloquize an English point of view. This moment hints at the inherent nationalism in language, the same kind of language Ionesco questioned in the ending of Englezește fără profesor. In the French, postwar version, he plays with cross-linguistic devices that reach back to incipient national violence in language only to negate it, further distancing himself from the wartime Romanian roots of the play. In the postwar version, now written in the victors' languages, he can openly criticize the same violence in language that he depicted with discomfort and ambivalence in the Romanian version.

Perhaps the most obvious trace of political violence in the French play is the target language of the textbooks Ionesco used: English. In 1950, learning the language of Great Britain-one of the Allied victors, now France's ally-fell in line with the postwar order. But in Vichy France in the 1940s, English was the language of the enemy. Ionesco worked in a France where language learning was a site of war. His propaganda work and the presence of nonnative people on French soil contributed to this war. Listening to British radio was an action punishable by forced labor or capital punishment. Also, under Nazi occupation, the number of French students taking German language classes skyrocketed (Wieviorka 23; Burrin 300-05). By choosing to use English, the language of the enemy, as the target language referred to in the play, Ionesco writes the play in languages made mutually hostile by the circumstances of war. This approach is consistent with the way he worked as a member of the Romanian delegation, whose policies set languages against each other. During the war, Ionesco used language manuals in Englezește fără profesor to point to how national governments use language to define the borders of inclusion and exclusion, of ally and enemy. As a Romanian civil servant in Vichy France, he moved between languages, layering one on top of the other, at a time when foreign languages were politically charged. His critical attitude toward ethnocentrism and the dominance of some languages over others can help us understand the multilingual aspects of the French play, the untranslated English phrases, as well as the translated portions of the play's Romanian-English and FrenchEnglish textbooks. 
The wartime Romanian play's origins in linguistic conflict leave their mark on $\mathrm{La}$ cantatrice chauve despite Ionesco's efforts to remove it. The French play does not present clichés and sounds as a sign of conformist language; rather, it deals with discovery through translation and linguistic exchange, as well as the often chaotic struggle to communicate, a struggle in which interlingual exchange can, but is not destined to, collapse. On stage we find the constructive politics of communication across languages. By reading the French play in historical, archival, and multilingual contexts, we can form a new understanding of it. In this reading, the play revolves around the possibilities of communication through language acquisition and the way political regimes can manipulate the very building blocks of language.

Echoes of the "apprentissage," "désapprentissage," and "réapprentissage" from Ionesco's dual-language youth continued into the postwar years, as Ionesco discovered that in his life language acquisition was linked to control by the state. When he was in the process of applying for French nationality in the 1950s, he was already known in France as a French playwright. But a form in his naturalization file entitled "Procès verbal d'assimilation" ("Statement of Assimilation") demonstrates that one of the main categories in this assessment of his assimilation to France was his language level: "nous avons constaté dans la mesure où nos moyens d'investigations nous l'ont permis, qu'il est (parfaitement) (bien) (assez bien) (peu) assimilé par ses mœurs, son état d'esprit, ses sentiments et qu'il parle (eotramment) (correctement) (passablement) (diffieilement) la langue française" "“we have observed insofar as our means of investigations have allowed us, that he is [perfectly] [well-] frather well] [little] assimilated in terms of his customs, mind-set, and sentiments and that he speaks the French language ffluently] [correctly] [passably] [with diffieulty]"). The French official who filled out this paperwork selected the option "correctement" ("well") for his language level. He did not assess Ionesco as a fluent speaker (one who speaks "couramment" ["fluently"]). At this point in his career, Ionesco was well on his way to becoming an important French author, and yet a minor bureaucrat considered his French to be inferior to that of a native speaker. This amazing statement only further demonstrates that in his ability to move between languages-in his acquisition of a language that opened up the possibilities of personal expression-he could not escape the state's purview. The irony of his life is that despite his literary success, he still struggled to fulfill the possibility of interlingual exchange.

\section{NOTES}

For their help and support I would like to thank Alice Kaplan, Ari Friedlander, Catherine Clark, Vlad Dima, and Eliana Văgălău, as well as the Andrew W. Mellon Foundation, the VolkswagenStiftung, and the Freiburg Institute for Advanced Studies.

1. Translations of French and Romanian throughout the article are my own, unless otherwise indicated. Although the titles of the play and textbook differ (Englezește means "in English"), they are translated in the same way. The critics who have discussed the Romanian play are Simion, Călinescu, and Hamdan. Impey laments: "much of the criticism devoted to Eugène Ionesco's theater utterly disregards the first draft of The Bald Soprano, which we now know was written in Romania in the thirties" (xiii). I have not found any proof that a version earlier than the one from 1943 exists. Few scholars address the Romanian version at length, aside from dating the French play to 1948 on the basis of a previous Romanian version, often undated (Jacquart, "Chronologie" lxxix and "Notice" 1461; Le Gall 265; Petreu 106; Plazy 59-60). Hamdan writes that Ionesco began the play in Romanian in 1948 (144). Neither Chafee nor Lane mentions the Romanian version. Bogdan holds that Ionesco laid the foundations of the play during the war but does not specify the language and says it is impossible to establish the exact circumstances of the play's origins (163). Vida mentions the Romanian version as an "Ur-Cantatrice" but does not analyze it and assumes that it too was based on the Assimil method. Vida deals not with 
the original wartime play but with the fascinating question of how to translate La cantatrice chauve into Romanian.

2. Simion discusses the original Romanian version in terms of the meaninglessness of language (317-38). Like Hamdan, he anchors Ionesco's theater of the absurd in the tradition of the Romanian avant-garde writers Ion Luca Caragiale and Urmuz.

3. My approach builds on important research by Laignel-Lavastine, Petreu, Simion, and Stan.

4. His exit visa was issued on 4 June 1940 ("Demande" [1940]).

5. For a discussion of Antonescu's policies and rise to power, see Deletant; Haynes.

6. Jacquart writes in the preface to the Pléiade edition of Ionesco's plays that Ionesco took refuge in the free zone in Marseille in 1942 and did translations for the Romanian delegation from time to time ("Préface" xxxix). In "Chronologie" Jacquart states more specifically that Ionesco joined the delegation, although Jacquart implies it was for financial reasons and after Ionesco's arrival in Marseille (lxxix). Lane simply states that Ionesco "spent the years 1942-44 in Marseille before settling in Paris in 1945 " (3). Lamont writes in her chronology of Ionesco's life, "1942: The Ionescos move to Marseille. They are poor refugees" (266). Esslin makes only one comment on Ionesco's wartime activities: "At the outbreak of war Ionesco was at Marseille. Later he returned to Paris" (Theatre 136). Călinescu writes that Ionesco took a purely cultural position without compromising himself politically or intellectually and argues that his post was even a form of legitimate self-defense (90). Hubert dedicates one sentence to Ionesco's return to France in 1942, without specifying what the playwright did during the war (36). Hamdan writes that Ionesco settled in Paris in 1938 but does not mention his wartime activities (12).

7. For a discussion of Antonescu's politics, see Stan $442,484$.

8. I am using Gienow-Hecht and Donfried's definition of cultural diplomacy (13).

9. Ionesco published Voronca's translations under the pseudonym Edouard Vallat (Ionescu, Report 1289). He indicates in a letter to Vianu that Vallat was Voronca's pseudonym (Letter).

10. The title La cantatrice chauve originates in a mistake that actor Jacques-Henri Huet made during rehearsals. He meant to say "l'institutrice blonde" ("the blond teacher"), but Ionesco liked this slip of the tongue so much he incorporated it into the play (Esslin, Theatre 140).

11. These lines correspond to scene 11 in the French version.

12. My translation maintains the rhyme. O rasă in English corresponds to race as in the human race, not as in a sports competition.

13. Învățați limba engleză fără profesor ("Learn English without a Teacher") is a title that numerous lin- guists have used for a number of textbooks. A textbook with a similar title was first published by Levițchi and Duțescu in the 1950s, too late for Ionesco to have used it. In addition, J. F. Magnasco published a textbook in 1912 whose title includes the expression fără profesor. As I have not located copies from the 1930s and 1940s, I do not rely on the content of the exercises, but instead I refer to the overall pedagogical philosophy of Levițchi and Duțescu as well as of textbooks of Ionesco's time, as illustrated by examples from Candrea; Mateiu; and Ghetu.

14. Later editions of the Fară profesor textbooks that are available include similar charts, indicating that phonetics exercises are part of the method (Levițchi and Duțescu 26).

15. Présent passé (1968) contains excerpts of Ionesco's diaries from the 1940s.

16. Spiridon has studied how starting from the 1848 revolutions in Moldavia, Walachia, and Transylvania against Ottoman and Austro-Hungarian rule, Romanian intellectuals structured identity discourse through borders, and especially symbolic spatial perimeters like the Danube.

17. Note that the names of the cities are given in Romanian in the original text but that the accents are missing.

18. According to Crane, the practice of compiling the commonplace book "created for English humanists a central transaction with antiquity" and a means to "frame" discourse. Commonplace books did not just contain imitations or mnemonic devices but also created a space in which intellectuals and students fashioned and interacted with authorial voices (3). Miller treats commonplaces as "textual memory" and the books in which they were written down as "a graphic site of participatory policy making through cultural continuities and social inventions" (6).

\section{Works Cited}

Bennett, Michael Y. Reassessing the Theatre of the Absurd: Camus, Beckett, Ionesco, Genet, and Pinter. Palgrave Macmillan, 2011.

Bogdan, Ghita. Eugène Ionesco: Un chemin entre deux langues, deux littératures. L'Harmattan, 2011.

Burrin, Philippe. La France à l'heure allemande, 19401944. Éditions du Seuil, 1995.

Călinescu, Matei. Ionesco: Recherches identitaires. Oxus, 2005.

Candrea, Ion-Aurel. I am learning English: Curs pratic de limba engleză. Cocec, circa 1938.

La cantatrice chauve. Jean-Luc Lagarce version, Arte France, 2007. DVD.

La cantatrice chauve. Nicolas Bataille version, 3 July 2013, Théâtre de la Huchette, Paris.

Casanova, Pascale. La république mondiale des lettres. Éditions du Seuil, 1999.

Chafee, Ingrid. "Exile in the Theatre of Ionesco." ParisBucharest, Bucharest-Paris: Francophone Writers 
from Romania, edited by Anne Quinney, Rodopi, 2012, pp. 173-96. Faux titre 367.

Chérel, A. L'anglais sans peine. Assimil, [1940-49?].

Crane, Mary Thomas. Framing Authority: Sayings, Self, and Society in Sixteenth-Century England. Princeton UP, 1993.

Deletant, Dennis. "Ion Antonescu: The Paradoxes of His Regime, 1940-44." In the Shadow of Hitler: Personalities of the Right in Central and Eastern Europe, edited by Rebecca Haynes and Martyn Rady, I. B. Tauris, 2011, pp. 278-94. International Library of Twentieth Century History 23.

“Demande de visa." 11 May 1940, Les archives de la Préfecture de Police, Paris, series IC, box 8 .

"Demande de visa et titre de voyage pour étranger." 1 July 1957, Les archives de la Préfecture de Police, Paris, series IC, box 8 .

Dragu, Ion. Report 559. 25 June 1942, Arhivele Naționale ale României, Ministerul Propagandei Naționale (1921-49), collection 2904, external press.

— Report 1158. 12 July 1943, Arhivele Naționale ale României, Ministerul Propagandei Naționale (192149), collection 2904

Esslin, Martin. Introduction. Absurd Drama, edited by Esslin, Penguin Books, 1965, pp. 7-23. Penguin Plays.

_. "The Theatre of the Absurd." Tulane Drama Review, vol. 4, no. 4, May 1960, pp. 3-15.

- The Theatre of the Absurd. Rev. updated ed., Vintage Books, 2001.

Ghetu, Zoe. Curs de corespondență comercială engleză, pentru uzul studenților. Socec, 1935.

Gienow-Hecht, Jessica C. E., and Mark C. Donfried. "The Model of Cultural Diplomacy: Power, Distance, and the Promise of Civil Society." Searching for a Cultural Diplomacy, Berghahn Books, 2010, pp. 13-29. Explorations in Culture and International History 6.

Hamdan, Alexandra. Ionescu avant Ionesco: Portrait de l'artiste en jeune homme. Peter Lang, 1993.

Haynes, Rebecca. "Germany and the Establishment of the Romanian National Legionary State, September 1940." Slavonic and East European Review, vol. 77, no. 4, Oct. 1999, pp. 700-25.

"L'histoire." Théâtre de la Huchette, www.theatre -huchette.com/un-peu-dhistoire/spectacle-ionesco/ lhistoire/. Accessed 25 Oct. 2016.

Hubert, Marie-Claude. Eugène Ionesco. Éditions du Seuil, 1990. Les contemporains 9.

Impey, Michael. Preface. Selected Poems of Tudor Arghezi, translated by Impey and Brian Swann, Princeton UP, 1976, pp. xiii-xxiii.

Ionesco, Eugène (see also Ionescu, Eugen). La cantatrice chauve. Ionesco, Théâtre complet, pp. 7-42.

_- Entre la vie et le rêve: Entretiens avec Claude Bonnefoy. P. Belfond, 1977.
. Letter to Tudor Vianu. 23 Dec. 1943. Scrisori către Tudor Vianu, by Tudor Vianu, vol. 2, Editura Minerva, 1994, p. 230.

_. Présent passé, passé présent. Mercure de France, 1968.

. Théâtre complet. Edited by Emmanuel Jacquart, Gallimard, 1991. Bibliothèque de la Pléiade 372.

"La tragédie du langage." Notes et contre-notes, Gallimard, 1962, pp. 155-60. Pratique du théâtre.

Ionesco, Eugène, et al. La terre roumaine: Emission du mercredi 29 septembre 1943. Arhivele Naționale ale României, Ministerul Propagandei Naționale (192149), collection 2905, propaganda. Transcript.

Ionescu, Eugen (see also Ionesco, Eugène). “Asupra unei noui emisiuni literare și artistice românești data de 29 Septembrie." 22 Sept. 1943, Arhivele Naționale ale României, Ministerul Propagandei Naționale (192149), collection 2905, propaganda.

. "Englezește fără profesor: Piesă inedită într-un act." Secolul 20, no. 1, 1965, pp. 57-66.

- Report 576. 13 Sept. 1942, Arhivele Naționale ale României, Ministerul Propagandei Naționale (192149), collection 2904, external press.

- Report 783. 22 Dec. 1942, Arhivele Naționale ale României, Ministerul Propagandei Naționale (192149), collection 2904, external press.

—_. Report 939. 2 Mar. 1943, Arhivele Naționale ale României, Ministerul Propagandei Naționale (192149), collection 2904, external press.

_ Report 1289. 22 Sept. 1943, Arhivele Naționale ale României, Ministerul Propagandei Naționale (192149), collection 2904, external press.

Jacquart, Emmanuel. “Chronologie.” Ionesco, Théâtre complet, pp. lxvii-cxviii.

. "Notice.” Ionesco, Théâtre complet, pp. 1461-87.

. "Préface." Ionesco, Théâtre complet, pp. xi-lxiii.

. Le théâtre de dérision: Beckett, Ionesco, Adamov. Gallimard, 1998.

Laignel-Lavastine, Alexandra. Cioran, Eliade, Ionesco: L'oubli du fascisme. PUF, 2002. Perspectives critiques.

Lamont, Rosette C. Ionesco's Imperatives: The Politics of Culture. U of Michigan P, 1993. Theater: Theory/Text/ Performance.

Lane, Nancy. Understanding Eugène Ionesco. U of South Carolina P, 1994. Understanding Modern European and Latin American Literature.

Le Gall, André. Ionesco: Mise en scène d'un existant spécial en son ouvre et en son temps. Flammarion, 2009.

Levițchi, Leon D., and Dan Duțescu. Învățați limba engleză fără profesor. Editura Științifică, 1959.

Magnasco, J. F. Românul în Englitera și Statele Unite: Cea mai nouă metodă de a invăța limba engleză în scurt timp fără profesor, cu intonatiune exactă în pronunțare. Polyglott Kuntze, 1912. 
Mareş, Nicolae. Eugen Ionescu: Diplomat român în Franța. Editura Fundației România de Mâine, 2012.

Mateiu, Sanda I. English book for the first year: Metoda Maud Griffiths-Belbin. Editura Cartea Românească, 1937.

Miller, Susan. Assuming the Positions: Cultural Pedagogy and the Politics of Commonplace Writing. $\mathrm{U}$ of Pittsburgh P, 1998. Pittsburgh Series in Composition, Literacy, and Culture.

Notes related to naturalization. Direction de la Police Générale, sec. 6, 18 Nov. 1956, Les archives de la Préfecture de Police, Paris, series IC, box 8.

Petreu, Marta. Ionescu în țara tatălui. 3rd ed., Polirom, 2012.

Plazy, Gilles. Eugène Ionesco: Le rire et l'espérance, une biographie. Julliard, 1994.

“Procès verbal d'assimilation.” 25 Sept. 1958, Les archives de la Préfecture de Police, Paris, series IC, box 8.

Radio announcement. Les nouveaux temps, 13 Oct. 1943, p. 2.

Radio announcement. Les nouveaux temps, 25 Jan. 1944, p. 2.
Register of wages. Serviciului Municipiului Bucureşti al Arhivelor Naționale, collection 1162, Liceul Sf. Sava, State Salarii, folders 2 (1925-29), 6-7 (1940-43).

Simion, Eugen. Le jeune Eugen Ionescu. Translated by Virgil Tanase, L'Harmattan, 2013.

Spiridon, Monica. "Identity Discourses on Borders in Eastern Europe." Comparative Literature, vol. 58, no. 4, 2006, pp. 376-86.

Stan, Ana-Maria. Relațiile franco-române în timpul regimului de la Vichy, 1940-1944. Argonaut, 2006.

Venuti, Lawrence. The Translator's Invisibility: A History of Translation. Routledge, 1995.

Vida, Raluca. "La méthode Assimil pour traduire La cantatrice chauve: Englezeste fara profesor." Lingua Romana, vol. 3, nos. 1-2, Fall 2004, linguaromana.byu .edu/2016/06/02/la-methode-assimil-pour-traduire-la -cantatrice-chauve-englezeste-fara-profesor/.

Wieviorka, Olivier. Histoire de la Résistance, 1940-1945. Perrin, 2013. 